\title{
ASUHAN KEPERAWATAN GIGI DAN MULUT PADA PASIEN DIABETES MELITUS (LAPORAN KASUS)
}

\section{Diyah Fatmasari $^{1}$, Muhammad Fiqih Sabilillah ${ }^{\otimes^{2}}$, Yodong $^{3}$}

\begin{abstract}
ABSTRAK
Dalam menentukan asuhan keperawatan gigi dan mulut, operator harus dapat mengenali tanda-tanda dan gejala kemungkinan pasien menderita penyakit sistemik sehingga mempengaruhi kondisi oral hygiene. Pasien yang sering berkunjung untuk memeriksakan gigi, diantaranya adalah pasien dengan penyakit diabetes melitus. Hal ini penting bagi operator untuk mengetahui penatalaksanaan pasien diabetes melitus sehingga dalam diagnosis dan merencanakan perawatan sesuai dengan kebutuhan. Operator juga dapat berkontribusi dalam pemeliharaan kesehatan gigi yang optimal dan peningkatan kualitas hidup pada pasien diabetes melitus dengan peningkatan manajemen oral hygiene dan pencegahan komplikasi. Laporan ini bertujuan untuk mengidentifikasi dan memahami asuhan keperawatan gigi dan mulut berdasarkan kebutuhan manusia dengan manajemen perilaku untuk pencegahan penyakit gigi dan mulut serta peningkatan status kesehatan gigi dan mulut.

Seorang pasien penyakit sistemik diabetes melitus terdapat Karies Dalam di oklusal pada gigi 16 dengan diagnosa Karies mencapai Pulpa Vital/Pulpitis. Asuhan keperawatan gigi dan mulut dilakukan dengan tujuan mengembalikan bentuk dan fungsi, mencegah karies lebih lanjut serta mengurangi rasa sakit. Tindakan yang dilakukan yaitu profilaksis pada gigi 16, Dental Health Education (DHE), Oral Physio Therapy (OPT) dan rujukan untuk perawatan saluran akar. Evaluasi perlu dilakukan secara teratur.

Asuhan keperawatan gigi dan mulut diharapkan dapat disusun secara sistematis sehingga penatalaksanaan pasien diabetes melitus dapat dilakukan berkesinambungan. Penatalaksanaan pasien diabetes melitus dibutuhkan komunikasi yang baik, hasil pemeriksaan laboratorium dan operator memahami penyakit diabetes melitus serta dampak setelah dilakukan perawatan gigi sehingga pasien diabetes melitus dapat menjalani proses perawatan gigi dan mulut dengan aman.
\end{abstract}

Kata Kunci : Asuhan Keperawatan Gigi dan Mulut, Pasien Diabetes Melitus.

\begin{abstract}
To determine dental and oral health care, operators must be able to recognize the symptoms and signs possibility patients suffer systemic disease should be detected as these influence oral hygiene condition. Patients who often visit dental clinic are patients with diabetes mellitus. It is important for operator to know dental management of patients with diabetes melitus therefore diagnosis and treatment can be drawn as needed. Operator also can contribute dental health care and improve quality life of patients diabetes melitus by improving oral hygiene management and complication prevention. Purpose of this report to identify and understand dental and oral health care based on human need with behavior management for dental disease prevention.

A diabetes melitus patient with caries occlusal 16 with diagnosis caries reach pulp visit dental clinic. Dental and oral health care to restore tooth shape and function, prevent further caries and reduce pain. Treatment for the patient was dental prophylaxis, dental health education and referral for root canal treatment. Evaluation need to be done regularly.

Dental and oral health care are expected to be systematically so that the management of patients with diabetes mellitus can be continue. Dental management patient with diabetes melitus need good communication, laboratorium test and knowledge of operator about diabetes melitus including the effect of dental care, therefore diabetic patient can undergo dental care safety.
\end{abstract}

Key words : Dental and Oral Health Care, Diabetic Patient

\footnotetext{
${ }^{1,3)}$ Dosen Jurusan Keperawatan Gigi Poltekkes Kemenkes Semarang

2) Mahasiswa Magister Saint Terapan Poltekkes Semarang

$凶$ : sabilillah_fiqih@yahoo.com
} 


\section{PENDAHULUAN}

Pembangunan sektor kesehatan nasional lebih diarahkan untuk meningkatkan derajat kesehatan yang optimal dengan upaya meningkatkan gizi, membudayakan hidup bersih, sehat serta meningkatkan kemandirian masyarakat untuk menolong dirinya sendiri dalam memelihara kesehatan giginya (Depkes, R.I., 2005). Pemeliharaan kesehatan gigi dapat dilakukan dengan asuhan keperawatan gigi dan mulut. Keperawatan gigi dapat dipahami sebagai ilmu pengetahuan dalam bidang kesehatan mulut preventif, termasuk didalamnya adalah manajemen perilaku untuk pencegahan penyakit gigi dan mulut serta peningkatan status kesehatan gigi dan mulut (Darby dan Walsh, 2003).

Dalam pelayanan asuhan keperawatan gigi dan mulut, diagnosa merupakan suatu proses berfikir kritis berdasarkan data-data klinis pasien yang dianalisa dan ditandai serta mengacu kepada teori kebutuhan manusia sebagai kerangka kerja konsepnya (Darby \& Walsh, 2005). Diagnosa keperawatan gigi menurut Wilkins (2005) diformulasikan berdasarkan kondisi masalah aktual, potensi masalah didalam rongga mulut pasien yang dapat dicegah, diminimalisir atau diatasi dengan tindakan perawatan mandiri atau kolaboratif (rujukan). Asuhan keperawatan gigi merupakan suatu pendekatan sistematis untuk mendapatkan informasi sehingga pasien mendapatkan perawatan (Jones, 2012), selanjutnya dibuat suatu perencanaan sesuai dengan kebutuhan pasien (CRDHA, 2009). Perencanaan perawatan ditulis secara resmi dan terperinci dalam meningkatkan derajat kesehataan gigi dan mulutnya (Wyche, dkk., 2009).

Dalam melaksanakan asuhan keperawatan gigi dan mulut, operator harus dapat mengenali tanda-tanda dan gejala kemungkinan pasien menderita penyakit sistemik yang dapat mempengaruhi kondisi oral hygiene. Pasien yang sering berkunjung untuk memeriksakan gigi, diantaranya adalah pasien dengan penyakit diabetes melitus. Hal ini penting bagi operator untuk mengetahui penatalaksanaan pasien diabetes melitus sehingga dalam mendiagnosis dan merencanakan perawatan disesuaikan dengan kebutuhan. Operator juga dapat berkontribusi dalam pemeliharaan kesehatan gigi yang optimal dan peningkatan kualitas hidup pada pasien diabetes melitus dengan melakukan peningkatan manajemen oral hygiene serta pencegahan komplikasinya (Azodo, 2009).

\section{PENATALAKSANAN KASUS}

Laporan kasus ini ditulis setelah menyelesaikan praktek belajar lapangan yang dilaksanakan di Rumah Sakit Umum Daerah Tugurejo Semarang. Laporan kasus ini merupakan kasus rujuk ke spesialis yang disertai penyakit sistemik dengan keluhan geraham kanan atas (gigi 16) terasa sakit dan mengganggu.

Penatalaksanaan kasus pada laporan ini mengacu pada asuhan keperawatan gigi dan mulut dengan tahapan yang akan dibahas dan dijabarkan sebagai berikut : tahap pertama yang dilakukan adalah pengkajian data. Pengkajian data meliputi identitas pasien dan pemeriksaan fisik. Pada pengkajian data didapatkan identitas pasien dengan inisial $\mathrm{Ny}$. K, berusia 46 tahun, beragama islam, suku jawa, pendidikan terakhir sarjana, pekerjaan swasta, golongan darah $\mathrm{O}$, beralamat di Semarang, kiriman dari puskesmas menggunakan pembayaran BPJS. Selanjutnya dilakukan pemeriksaan fisik. Pemeriksaan fisik yang dilakukan yaitu dengan memeriksa tanda-tanda vital dan skrining nutrisi. Tanda-tanda vital yang dilakukan pada pasien tersebut meliputi, pemeriksaan tekanan darah $(142 / 90 \mathrm{mmHg})$, frekuensi nadi (102 X/mnt), frekuensi nafas (24X/mnt) dan pengukuran suhu tubuh $\left(37^{\circ} \mathrm{C}\right)$. Setelah pemeriksaan tanda-tanda vital selesai, maka dilakukan pemeriksaan skrining nutrisi. Pemeriksaan skrining nutrisi yang dilakukan pada pasien tersebut diantaranya, keadaan umum pasien (kurang 
baik), berat badan $(63 \mathrm{~g} / \mathrm{Kg})$ dan tinggi badan $(150 \mathrm{~cm})$

Selanjutnya tahap kedua yang dilakukan adalah diagnosa. Diagnosa yang dilakukan meliputi pemeriksaan subyektif, pemeriksaan obyektif dan faktor-faktor yang harus diperhatikan. Pemeriksaan subyektif meliputi anamnesa (keluhan utama dan keluhan tambahan), riwayat kesehatan gigi sekarang, riwayat kesehatan lain. Setelah dilakukan pemeriksaan subyektif, didapatkan anamnesa dengan keluhan utama pasien datang dengan keluhan gigi belakang kanan atas terasa sakit saat digunakan mengunyah makanan satu minggu yang lalu, dulu satu bulan yang lalu pernah terasa sakit, sekarang sakit lagi dan ingin dirawat. Tidak ada keluhan tambahan yang dirasakan pasien.

Pada pemeriksaan riwayat kesehatan gigi sekarang, pasien mendapat 10 pertanyaan yang harus dijawab. Pertanyaan tersebut diantaranya adalah

1. Apakah pernah sakit/lint pada gigi? Ya, pernah

2. Gigi mana yang sakit/linu? Gigi belakang kanan atas

3. Kapan rasa sakit/linu ini mengganggu? 1 minggu yang lalu

4. Apa yang menimbulkan rasa sakit/linunya? saat digunakan mengunyah makanan

5. Berapa lama rasa sakit/linu ini bertahan? $10 \mathrm{~s} / \mathrm{d} 15$ menit

6. Kapan pertama kalinya timbul rasa sakit ini? 1 bulan yang lalu

7. Pada daerah mana dimulainya rasa sakit ini? Pada gigi belakang

8. Apakah rasa sakit tersebut dirasakan pada tempat yang sama sebelumnya? Ya

9. Apakah ada yang menyebabkan rasa sakit berkurang? Setelah minum obat

10. Apakah rasa sakit tersebut mengganggu waktu tidur? Ya

Setelah pasien menjawab 10 pertanyaan tersebut, kemudian dilakukan pemeriksaan riwayat kesehatan yang lain dengan cara menggali informasi dari pasien. Pasien diberi pertanyaan mengenai penyakit yang pernah dialami pada masa kanak-kanak (tidak pernah), kecelakaan (tidak pernah), pernah dirawat dengan jenis penyakit dan waktunya serta operasi (tidak pernah). Alergi pada pasien tidak ada. Immunisasi pernah dilakukan oleh pasien tetapi pasien tidak tahu nama dan jenisnya. Kebiasaan buruk tidak ada dengan frekuensi menyikat gigi $2 x$ sehari yaitu pagi dan sore saat mandi. Obat-obatan yang diminum (nama dan lamanya : tidak ada, sendiri/ resep dokter : tidak ada).

Setelah pemeriksaan subyektif selesai dilakukan, maka selanjutnya dilakukan pemeriksaan obyektif. Pemeriksaan obyektif meliputi pemeriksaan ekstra oral dan intra oral. Pemeriksaan ekstra oral dilakukan pemeriksaan pada facial (simetris/ asimetris), kelenjar sub mandibular kanan (teraba/ tidak teraba, keras/lunak, sakit/ tidak sakit) dan kiri (teraba/ tidak teraba, keras/lunak, sakit/ tidak sakit) serta kelainan dentofacial (ada/ tidak ada).

Kemudian pada saat dilakukan pemeriksaan intra oral, terdapat gigi 16 (kode 2 karies) terlihat karies dalam di oklusal (inspeksi) dengan termis dan sondasi positif (+) namun perkusi dan mobility negatif (-). Masalah keperawatan gigi yang didapatkan setelah berbagai pemeriksaan yaitu Karies Mencapai Pulpa (KMP) Vital dengan diagnosa pulpitis.

Setelah pemeriksaan subyektif dan obyektif selesai maka dilakukan pemeriksaan faktor-faktor yang harus diperhatikan. Faktor-faktor yang perlu diperhatikan meliputi keadaan gigi/anomali gigi dan keadaan mukosa mulut. Keadaan gigi/anomali gigi pada pasien tersebut didapatkan posisi gigi dengan mesioversi 21 , 31 , labioversi 41 , jumlah gigi sebanyak 26 gigi tetap, bentuk gigi pada pasien normal dan enamel juga normal. Selanjutnya dilakukan pemeriksaan keadaan mukosa mulut pada pasien meliputi lidah (normal), palatum (normal), pipi (normal), bibir (normal) dan gingiva. Keadaan gingiva yang perlu diperhatikan dan didapatkan pada pasien adalah konsistensi (kenyal, lunak), bentuk papil (runcing, bulat), bentuk margin (normal, abnormal), warna (merah muda) 
dan data/ masalah yang diderita pasien (tidak ada inflamasi).

Selanjutnya tahap ketiga yang dilakukan adalah rencana perawatan gigi.Tahap perencanaan meliputi promotif, preventif, eksodonsia, konservasi dan lainlain. Apabila terdapat kasus yang tidak sesuai dengan kompetensi maka harus segera dikonsulkan sesuai dengan bidangnya. Pada pasien ini akan dilakukan perencanaan preventif dengan tindakan DHE, OPT, Scalling dan TAF, sedangkan gigi 16 yang menjadi keluhan akan dikonsulkan kepada spesialis. Setelah menjalani tahap rencana perawatan gigi, pasien harus dijelaskan secara lisan dan pasien menyetujui secara tertulis dibuktikan dengan informed consent (ic).

Tahap selanjutnya yaitu tahap keempat. Pada tahap keempat dilakukan analisa data dengan menganalisa dan menghubungkan data yang didapat, kemungkinan penyebab dan masalah keperawatan gigi. Data yang didapat dari pasien yaitu 16 dengan diagnosa Karies Mencapai Pulpa Vital, terlihat Karies dalam di oklusal. Kemungkinan penyebab yang dialami pasien diantaranya adalah teori karies 4 faktor, kurang pengetahuan tentang kesehatan gigi dan mulut, tidak taat dalam menggosok gigi, kurang perawatan diri dan penyakit gigi yang tidak dirawat. Masalah keperawatan gigi yang terjadi pada pasien dapat disimpulkan dengan tidak terpenuhinya kebutuhan kondisi biologis yang baik, tidak terpenuhinya kebutuhan kemandirian dan tanggung jawab dan tidak terpenuhinya kebutuhan dari rasa sakit.

Berdasarkan tahapan yang dilakukan diatas maka selanjutnya dilakukan perencanaan, pelaksanaan dan evaluasi. Hal pertama yang dilakukan pada tahap ini adalah melakukan perencanaan intervensi. Perencanaan intervensi pada pasien difokuskan pada gigi 16 dengan diagnosa Karies Mencapai Pulpa Vital, terlihat Karies dalam di oklusal. Pada kunjungan I dilakukan profilaksis dan pro PSA sehingga tindakan/perawatan klinis yang dilakukan adalah pembersihan kavitas gigi dan perawatan saluran akar sehingga dirujuk ke dokter gigi spesialis konservasi. Penyuluhan/ konseling yang dilakukan sesuai dengan penyebab masalah yaitu dengan cara melakukan Dental Health Education (DHE), konseling mengenai penyebab, akibat dan pencegahan karies. Selanjutnya diberikan instruksi perawatan gigi di rumah dengan memberikan instruksi cara menyikat gigi, waktu yang tepat menyikat gigi, makanmakanan yang menyehatkan, kontrol 3-6 bulan sekali, memeriksakan gigi minimal 2 kali setahun dan diberikan leaflet.

Selanjutnya, hal kedua yang dilakukan adalah menjelaskan tujuan dan menentukan waktu pelaksanaan (perawatan). Tujuan perawatan gigi 16 dengan diagnosa Karies Mencapai Pulpa Vital, terlihat Karies dalam di oklusal adalah mengembalikan bentuk dan fungsi, mencegah karies lebih lanjut serta mengurangi rasa sakit sedangkan waktu pelaksanaan (perawatan) kunjungan pertama yaitu tanggal 02 Mei 2015, telah dilakukan pembersihan kavitas gigi dan telah dilakukan rujukan. Cara evaluasi yang dilakukan dengan memberikan instruksi kontrol setelah satu minggu perawatan.

\section{PEMBAHASAN}

Diabetes melitus merupakan penyakit kronis yang dapat diminimalisir melalui obat-obatan dan perubahan gaya hidup. Penyakit sistemik dan penyakit gigi dan mulut dapat terjadi sebagai akibat penyakit diabetes melitus. Seluruh tenaga kesehatan harus berperan aktif dalam mengidentifikasi penyakit pada individu yang terkena penyakit diabetes melitus namun tidak terdiagnosis, kemudian membantu pasien diabetes melitus dalam meminimalisir dan mencapai kesehatan yang optimum (Gurenlian, dkk, 2008).

Pasien diabetes melitus dianjurkan agar memeriksakan gigi setiap 3 atau 4 bulan. Semua jaringan ditangani dengan lembut untuk meminimalkan trauma. Pasien 
diabetes melitus harus diajarkan untuk mengikuti jadwal pembersihan sesuai dengan prosedur. Operator mungkin perlu membantu pasien diabetes melitus dalam merawat dan memelihara kesehatan gigi dan mulutnya karena berpotensi menyebabkan penyakit periodontal (Smeltzer, Bare, 1992.,cit. Potter \& Perry, 2006).

Faktor risiko masalah kesehatan gigi dan mulut pada pasien diabetes melitus adalah pasien cenderung kering pada mulut/xerostomia, terdapat gingivitis, penyakit periodontal dan kehilangan gigi (Phipps, 1995., cit. Potter \& Perry, 2006). Pasien diabetes melitus dianjurkan membangun aturan perawatan gigi dan mulut setelah makan dan waktu tidur, yaitu dengan cara menggosok gigi dengan sikat gigi yang lembut menggunakan gerakan horizontal. Menggosok gigi yang konsisten meningkatkan jaringan gusi, mengurangi kotoran dan menghasilkan pengontrolan plak (Khan, 1986., cit. Potter \& Perry, 2006).

Sikat gigi yang lembut dengan gerakan horizontal dapat membantu melindungi jaringan gusi yang lembut dan mencegah perdarahan (Crosby, 1989., cit. Potter \& Perry, 2006). Pasien diabetes melitus diharapkan melakukan higiene mulut dan sesekali berkumur dengan air garam atau larutan baking soda (1/2 sendok teh dengan $473 \mathrm{~mL}$ air). Berkumur dengan air garam atau baking soda dapat melarutkan keasaman mulut, mengangkat debris dan mengurangi mulut yang kering/xerostomia (Greifzu, Radjeski, Winnick, 1990., cit. Potter \& Perry, 2006).

Pada pasien diabetes mellitus umumnya mempunyai masalah kesehatan gigi dan mulut dikarenakan kadar gula yang tidak terkontrol. Dengan adanya unsur glukosa yang tinggi dalam saliva menyebabkan saliva menjadi satu perbenihan yang efektif. Medium ini menyerap sisa-sisa makanan yang menjalar pada sepertiga leher gigi sehingga terjadi akumulasi yang cepat dari bakteri, mengakibatkan hasil metabolisme bakteri tersebut masuk ke sulcus gingiva. Hasil pemecahan metabolisme ini kemudian bereaksi sebagai suatu sumber iritasi yang terus menerus menghasilkan reaksi jaringan yang berlebih pada pasien diabetes melitus.

Diabetes melitus merupakan penyakit gangguan metabolisme tubuh yang disebabkan hormon insulin yang diproduksi kelenjar pankreas tidak berfungsi. Insulin berfungsi mengontrol kadar gula dalam darah dengan mengubah karbohidrat, lemak dan protein menjadi energi. Diabetes melitus yang tidak terkontrol dapat mengganggu sel darah putih dan sel-sel imun seperti neutrofil, monosit dan makrofag. Hal tersebut mengakibatkan kemampuan tubuh untuk melawan bakteri menjadi menurun dan lebih rentan terhadap terjadinya infeksi. Selain itu dengan adanya peningkatan sel radang dalam cairan saku gingiva maka menyebabkan jaringan periodontal lebih mudah terinfeksi sehingga dapat berakibat kerusakan tulang. Rusaknya jaringan periodontal membuat gingiva tidak lagi melekat ke gigi, tulang menjadi rusak dan dalam jangka waktu yang panjang dapat berakibat gigi menjadi goyang.

Diabetes melitus yang tidak terkontrol juga dapat menyebabkan karies, dikarenakan bertambahnya komponen yang difermentasi di dalam saliva sehingga membentuk medium yang sesuai untuk pembentukan asam. Selain itu luka yang terjadi pada pasien diabetes melitus sukar sembuh, hal ini disebabkan karena adanya gangguan aliran darah ke tempat terjadinya luka sehingga penyembuhan luka akan lebih sulit dan lebih lama.

Tenaga kesehatan khususnya dalam bidang keperawatan gigi dan mulut diharapkan mengetahui sifat serta tandatanda penyakit diabetes melitus yang terdapat pada rongga mulut sehingga mengetahui tindakan apa yang akan dilakukan dalam rangka mencegah berbagai faktor risiko yang dapat terjadi.

$$
\text { Dalam pelayanan }
$$

asuhan

keperawatan gigi dan mulut, terdapat banyak aktifitas pengambilan keputusan dari saat tahap pengkajian, diagnosa, perencanaan, 
implementasi dan evaluasi. Tahap pelayanan asuhan keperawatan gigi dan mulut adalah sebagai berikut :

1. Tahap Pengkajian

Pada tahap ini, operator mengumpulkan informasi untuk mengkaji kebutuhan pasien dari berbagai sumber. Masing-masing sumber berkontribusi secara unik terhadap hasil pengkajian secara keseluruhan. Hasil penelitian dapat membantu dalam memilih alternatif metode.

Tahap pengkajian merupakan fondasi yang akan digunakan dalam proses keperawatan gigi. Pengkajian adalah suatu proses mengumpulkan dan menganalisis informasi atau data-data dalam mengkaji kebutuhan pasien dari berbagai sumber. Informasi yang didapat melalui wawancara dengan pasien, anggota keluarga, teman sejawat, tenaga kesehatan lain, rekam medis dan observasi. Informasi yang didapat dari berbagai macam sumber tersebut berkontribusi secara unik terhadap hasil pengkajian secara menyeluruh.

2. Tahap Diagnosa

Tahap ini, hasil penelitian yang dapat digunakan dalam menegakkan diagnosa keperawatan gigi secara akurat dan memahami batasan karakteristik diagnosa. Diagnosa ditegakkan berdasarkan pada kebutuhan pasien, menguraikan masalah-masalah aktual, mencegah atau meminimalisir faktor risiko dengan perawatan mandiri atau melakukan rujukan (kerjasama dengan tenaga kesehatan lainnya) dan identifikasi kondisi pasien berdasarkan risiko terjadinya masalah/penyakit/kelainan pada rongga mulut.

3. Tahap Perencanaan

Pada tahap ini, hasil penelitian yang dapat digunakan antara lain hasil penelitian yang mengindikasikan intervensi keperawatan gigi yang efektif untuk diaplikasikan sesuai kebutuhan. Tahap perencanaan merupakan tindakan penentuan tipe intervensi keperawatan gigi yang dilaksanakan (diimplementasikan) untuk mengatasi keluhan pasien dan membantu pasien dalam mencapai pemenuhan kebutuhan yang berhubungan dengan kesehatan gigi.

4. Tahap Implementasi

Tahap implementasi adalah tindakan pelaksanaan perencanaan keperawatan gigi dan mulut yang telah dirancang sesuai dengan pemenuhan kebutuhan pasien dan dilaksanakan berdasarkan prosedur serta hasilnya tercatat dalam catatan pasien (catatan keperawatan gigi). Operator diharapkan dapat bertanggung jawab dalam melakukan intervensi keperawatan gigi berdasarkan pada hasil-hasil penelitian terkini.

5. Tahap Evaluasi

Pada tahap ini, evaluasi dilakukan untuk menilai intervensi yang dilakukan berdasarkan perencanaan sudah berhasil dan menilai efektifitas dari segi biaya. Hasil penelitian yang digunakan adalah hal yang terkait keberhasilan ataupun kegagalan dalam suatu pemberian asuhan keperawatan gigi. Evaluasi juga dilaksanakan dalam rangka mengukur respon pasien terhadap tindakan keperawatan gigi demi kemajuan pasien kearah pencapaian tujuan. Evaluasi dianalisis dari tahap pengkajian data sampai dengan tindakan/intervensi yang dilakukan kepada pasien.

\section{KESIMPULAN}

Asuhan keperawatan gigi dan mulut diharapkan dapat disusun secara sistematis sehingga penatalaksanaan pasien diabetes melitus dapat dilakukan berkesinambungan. Penatalaksanaan pasien diabetes melitus dibutuhkan komunikasi yang baik, hasil pemeriksaan lab dan operator memahami penyakit diabetes melitus, pengobatan, juga dampaknya sehingga pasien diabetes melitus dapat menjalani proses perawatan gigi dan 
mulut dengan aman. Manajemen dan teknis pelaksanaan disusun dalam perencanaan jangka pendek dan jangka panjang kemudian dievaluasi sehingga didapatkan hasil yang optimal dan membangun kemandirian serta kesadaran pasien dalam merawat giginya.

\section{DAFTAR PUSTAKA}

Azodo., 2009, Current trends in the management of diabetes mellitus: the Dentist's perspective, Journal of Postgraduate Medicine, Nigeria. Hal 113-129.

College of Registered Dental Hygienists of Alberta,.2009, The Dental Hygiene Process of Care (Registrants Handbook), Journal Practice Standards College of Registered Dental Hygienists of Alberta. Edmonton, AB: CRDHA, section 5, Hal 1-21.

Darby dan Walsh., 2003, Dental Hygiene Theory And Practice 2nd Edition, Sander, Missouri-USA, Hal : 345367.

Darby dan Walsh., 2005, Dental Hygiene Theory And Practice 2nd Edition, Sander, Missouri-USA.

Departemen Kesehatan R.I., 2005, Kebijakan Nasional Promosi Kesehatan, Pusat Promosi Kesehatan, Jakarta.

Gurenlian R Joann, dkk., 2008, Diabetes Mellitus: Promoting Collaboration among Health Care Professionals, Journal of Dental Hygiene, the American Dental Hygienests Association, Vol. 83, Hal 1-13.

Jones., 2012, The Dental Hygiene Process of Care (Registrants Handbook), Journal Standards of Practice, College of Dental Hygienists of
Ontario (CDHO), Toronto, Orascoptic, Hal 1-19.

Potter \& Perry., 2006, Buku Ajar Fundamental Keperawatan : Konsep, Proses, dan Praktik. Edisi 4. Volume 2. Alih Bahasa : Renata Komalasari, dkk. Jakarta: EGC.

Wilkins, EM., 2005, Clinical Practice of Dental Hygienist 9th edition, Lippincot Williams \&Wilkins, Massachusetts-USA. Hal 323-912.

Wyche CJ, dkk., 2009, Planning for Dental Hygiene Care, Journal Dental Hygiene Diagnosis and Care Planning, Section 4, Chapter 21, Hal 353-368. 